\title{
CXXC5 wt Allele
}

National Cancer Institute

\section{Source}

National Cancer Institute. CXXC5 wt Allele. NCI Thesaurus. Code C152031.

Human CXXC5 wild-type allele is located in the vicinity of $5 q 31.2$ and is approximately $7 \mathrm{~kb}$ in length. This allele, which encodes CXXC-type zinc finger protein 5, is involved in the modulation of signaling, the regulation of apoptosis and transcriptional regulation. 